\title{
Greenwashing, Does it Work Well for Indonesian Millennial Buyers?
}

\author{
Agustina Fitrianingrum*, Selly Celsya \\ Management Study Program \\ Universitas Internasional Batam \\ Batam, Indonesia \\ *agustina@uib.ac.id
}

\begin{abstract}
Greenwashing has been used by certain international companies as the strategy to improve the branding of products or services since years ago. Greenwashing defined as a promoting activity of green products or services that lead customers to have a perception and expectation beyond what products or services is delivered to them. This research is intended to reveal the empirical study regarding the power of greenwashing to influence purchase intention amongst millennials buyers of a low involvement product in Indonesia, specifically in Batam. Respondents are chosen using purposive sampling among millennials (age 22-35). This group is considered as a group of customers who are willing to pay a premium price for green products/services compare to $X$ (age 36-54) and Baby Boomers (age 55-64) generations. Data is gathered by an online survey involving 195 millennials who are willing to choose mineral water that promoted as ecofriendly products. To analyze further structured equation modeling is applied to reveal the relationship among factors. The positive relationship of brand credibility to brand equity is shown its effect on millennials' purchase intention. In contrast, Greenwashing has a negative effect on the relationship. This indicates that Indonesian millennials are aware of greenwashing practices. The research reveals the applicability of the DNA model as the extent of Resource Advantage Theory to sustain the business by integrating the dynamic capability, core idea and societal engagement to improve companies' social and financial performance.
\end{abstract}

Keywords—greenwashing, brand credibility, brand equity, Indonesian millennials, purchase intention

\section{INTRODUCTION}

Innovation becomes the source to attract customers' purchase behavior for sustaining the business in a disruptive era. The statement sounds less positive if it is translated that innovation of products or services is purposed to drive the customers to consume in excessive ways because the company's activities in terms of production, distribution, and consumer consumption have a significant impact on the environment. Therefore, innovation should not be limited to products or services but in the entire organization's business operation. The study conducted in Spain reveals that sustainability orientation is a driver of innovation in utilities industries [1].

People are now more aware of environmental damage which mostly is caused by industry, it pollutes water, air and soil pollution. Based on the report there are 275 million metric tons (MT) of plastic waste were generated in 192 coastal countries in 2010 , with 4.8 to 12.7 million MT entering the ocean [2]. It shows that global waste generated from the industrial sector is dominated by packaging waste, especially plastic waste at $36 \%$, followed by building and construction waste at $16 \%$. Indonesia is reported as the second-highest level of the country in producing waste, which is produced more than 3 million metric tons of mismanaged plastic waste annually [3]. While another report stated that this modest percentage is composed of an estimated 1.8 trillion pieces of plastics in the garbage patch, of which microplastics are estimated to make up $94 \%$ of this total [4]. This fact generates customers' awareness to contribute to saving the environment. Moreover, Environmentalists encourage people to be more proactive and open in their consumption of environmentally friendly products. The good news consumers are positively responding to reduce the problem of natural issues by choosing environmentally friendly products or services. This condition is opening opportunities for a company to fulfill the high demand for eco-friendly products or services. Companies have been starting aggressively to create Go Green movement either by adopting environmentally friendly management systems or using Green Branding in marketing, starting from the use of biodegradable packaging and materials that are environmentally friendly, cruelty-free or do not use materials from animals to the production process that is not harmful to the environment [5]. However, companies consider this practice to incur higher costs, and will also create difficulties for companies such as resources that are difficult to find. This assumption causes company doing Greenwashing practices as their strategic marketing either intentional or not. The new jargon of these activities is introduced as "The Green is the New Black" [6].

Greenwashing is a real phenomenon but identifying its practices is also not easy for consumers. It will be very difficult to distinguish which companies are truly engaged in caring for 
the environment itself. Greenwashing practices generating negative feedback for consumers who concern about green practices and certainly put companies that are doing the green movement in difficult position. Doing Greenwashing would certainly affect consumers' doubts in consuming their products [7].

In Indonesia, three labels considered as the sign of ecolabel product which is published by Ecolabel Index [8]. They are Ekolabel (is found on retail goods in Indonesia), Lembaga Indonesia Ekolabel or The Indonesian Ecolabelling Institute (non-profit organization that develops forest certification systems that promote sustainable forest resource management in Indonesia), and M-BRIO Organic and Food Labeling (Organic food labelling). The main driver of purchasing environmentally friendly products is the presence of environmental orientation and the ecolabel listed on the products [9]. The ecofriendly products are applying the green label. Label of product is related to brand credibility that will influence the brand equity of product or services. Furthermore, it is found the significant relationship of Brand Equity as the predictor of purchase intention [9].

The study is intended to reveal the empirical research of greenwashing to purchase intention and its relation with Brand Credibility and Brand Equity. Since very limited empirical research of greenwashing in Indonesia, this research is intended to reveal the empirical study regarding the power of greenwashing to influence purchase intention amongst millennials buyers in Indonesia, specifically in Batam who prefer to choose plastic eco-friendly drinking water. Drinking water is considered a low involvement product. However, bottle plastic is considered the most rubbish in the ocean. Therefore, drinking water companies have been trying to produce a more ecofriendly product.

The Millennials is a group of young generations age 22-35 who are willing to pay a premium price for green products/services compare to X (age 36-54) and Baby Boomers (age 55-64) generations. In 2017, WWF-Indonesia and Nielson published a report that $61 \%$ of people have concerned about the global warming effect and $63 \%$ of respondents are also willing to buy ecolabel products even though the price is higher [10]. Moreover, Indonesia is an emerging market with a top big five population in the world. It means that the behavior of Indonesian millennials will contribute to a significant marketing strategy that will be implemented by international brands. The perspective of the DNA model as the extent of Resource Advantage Theory to sustain the business is the merit of this study.

\section{LITERATURE REVIEW}

\section{A. DNA Model: The extended of Resource Advantage Theory}

DNA is literally the characteristic of a person that applies to every individual. When it applies to the firm's DNA, it means that the DNA of a firm will be the characteristic of a firm itself. It will distinguish a firm from another. DNA Model is an extended model developed by Hunt and Morgan who introduced a theory, namely Resource-Advantage Theory, which is constructed of three multidimensional: DNA, stakeholder involvement, and performance management. DNA Model is developed as a guideline of academicians and practitioners to explore the underlying market-oriented generally intangible constructs that precipitate sustainability efforts [11]. DNA Model as first and independent construct consists of DNA (Core Ideology, Dynamic Capabilities, Societal Engagement). The second construct is Stakeholder Involvement as a moderating variable and the last construct is Performance Management (Social and Financial Performance).

These can be basic values and believes that reflected firms' culture and norms to shape sustainability activities [11]. It emphasized that Brands are considered as one of the most important intangible assets owned by companies and it's the essence of a firm [11]. The internal and external parties of a firm can feel what the value of the brand is when it is well communicated with all stakeholders. This framework highlighted the importance of integrating marketing strategy (market orientation) and sustainability to ensure the long-term welfare of all stakeholders. This is where performance management is not heavily relying on financial but also nonfinancial measurement.

In 1995, Hunt and Morgan introduced Resource-Advantage Theory. It is said that a firm can achieve competitive advantage and superior long-run performance by a market-oriented firm, whereas made a firm has an intangible resource. To create a clear relevance of Resource-Advantage Theory to the context, Crittenden et al. extended the theory by developing DNA Model [11]. DNA Model which constructed of three multidimensional: DNA, stakeholder involvement, and performance management. DNA Model is developed as a guideline of academicians and practitioners to explore the underlying market-oriented generally intangible constructs that precipitate sustainability efforts. As its first and independent construct consists of DNA (Core Ideology, Dynamic Capabilities, Societal Engagement). The second construct is Stakeholder Involvement as moderating variable and the last construct is Performance Management (Social and Financial Performance)

\section{B. Greenwashing}

Greenwashing is defined as the intersection of two firm behaviors: poor environmental performance and positive communication about environmental performance [12]. Greenwashing is the act of misleading consumers regarding the environmental practices of a company (firm-level greenwashing) or the environmental benefits of a product or service (product-level greenwashing) [12]. It is reported in US and Canada, The TerraChoice Group categorized product-level greenwashing into "seven sins" as follows:1) Sin of the hidden trade-off: intentionally suggesting a product is "green" based on a narrow subset of attributes (e.g., paper produced from a sustainably harvested forest may still yield significant energy and pollution costs); 2) Sin of no proof: claimed that the 
product is ecofriendly but difficult to verify (e.g., paper recycled content without showing any evidence). 3) Sin of vagueness: broad claim that easily misunderstood by consumer (e.g., "all-natural"); 4) Sin of irrelevance: truthful committed by making an environmental claim but unimportant for consumers (e.g., "CFC-free" is unimportant because chlorofluorocarbons are restricted by law); 5) Sin of lesser of two evils: claim is true but risk consumers from the greater health or bad impacts (e.g., organic cigarettes); 6) Sin of fibbing: committed by making environmental claims that are simply false (e.g., products falsely claiming to be Energy Star certified);7) Sin of false labels: intentionally using fake label to exploit consumers with eco-friendly jargon (e.g. "ecopreferred") [13].

Greenwashing is confusing consumers and builds skepticism of the real ecofriendly product. Therefore, previous researches find that greenwashing give a negative effect on green WOM, green perceived quality and green satisfaction [14]. Greenwashing gives a negative effect on green brand equity, brand credibility, green brand associations and purchase intention [9]. It is also reported that greenwashing practices carried out by companies to get an image that they are more environmentally friendly and contributing higher CSR values [6].

H1: Greenwashing has a significant negative effect on brand credibility a low involvement product.

\section{Brand Credibility}

A brand is the most valuable asset for a firm and the brand has been widely recognized as an important and main reason for consumers to choose [11]. Brand credibility a level of trustworthiness, in which firms deliver their promise. The credibility of a brand is not easy to build, must be consistent, transparent and avoid the ambiguous perception of a firm. Brand Credibility is the level of trust in the information contained in a brand [9]. The brand is a tool for consumers to assess the uniqueness and quality of a product that increases consumer's confidence when they make decisions. Hence, it can be the distinctive character of a firm [15]. If a brand has an ability that can be trusted by consumers, the credibility of the brand will be better [9]. Building a close relation and collaborate with agencies, institutions, and groups that have environmental orientation will help a firm to build green brand credibility [16]. Previous research found that greenwashing to negatively affect brand credibility [6,14,17]. Moreover, it stated that greenwashing forms consumer confusion increases risk perception and negatively affects green trust [9]. It will be very difficult for companies to build brand credibility when cynicism and uncertainty felt by consumers. Furthermore, it is stated that higher credibility will strengthen brand equity. In other words, brand credibility is the main pillar that can be built by companies to increase the brand equity of a brand.

$\mathrm{H} 2$ : Brand credibility has a significant positive effect on green brand equity a low involvement product.

\section{Green Brand Equity}

In this study, green brand equity applies the definition that it is as a set of brand assets and liabilities about green commitments and environmental concerns linked to a brand, its name and symbol that add to or subtract from the value provided by a product or service [18]. It is chosen because brand equity is the result of the subconscious and conscious minds of consumers. To reach brand equity, the surface level is the awareness of a customer to a brand, loyal to a brand and then associate a brand to a certain perception. Therefore, brand equity is a real form of a firm's competitive advantage [11].

The green brand equity is conceptualized as a set of brand assets and liabilities about green commitments and environmental concerns linked to a brand, its name, and symbol that add to or subtract from the value provided by a product or service [19]. These should be well communicated to customers as [20] stated that a firms' position and performance related to the environment can be the key factors for green brand equity. Previous studies show supportive results that brand equity has a positive influence on purchase intention [9].

H3: Green brand equity has a significant positive effect on green purchase intention a low involvement product.

\section{E. Green Purchase Intention}

Green purchase intentions are a subjective probability that consumers will make purchases or purchases of environmentally friendly products (green products). Green purchase intention is a complex concept that is influenced by many factors such as, characteristics of environmentally friendly consumers, factors about marketing and brand-related factors, including price, promotion, quality, trust, and attention to the environment [9]. The previous study concluded that consumer purchase intention is also driven by a behavior towards a brand, where when the behavior is positive, the purchase intention will be higher, but if the behavior is negative, then the purchase intention for a product will also decrease [21].

The study about greenwashing and green purchase behavior in Taiwan explored the mediating role of green brand image and customer loyalty. The results of the study indicated that greenwashing activity has a negative influence on consumer buying behavior. Moreover, this study reveals that greenwashing has a negative relationship with brand image and brand loyalty where both variables have a positive influence on green purchase behavior [18].

H4: Greenwashing has a significant negative effect on green purchase intention of a low involvement product.

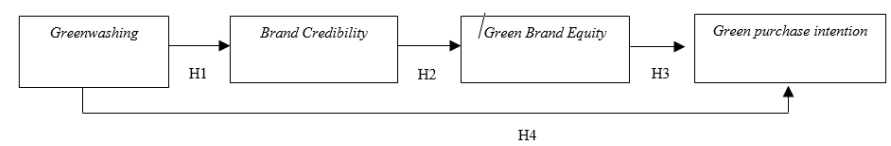

Fig. 1. Research framework. 


\section{METHODS}

The object of the study is bottle drinking waters which recognized as a green product. The product of bottled drinking water is considered a low involvement product because consumers do not put high consideration when purchase. The sampling applied is purposive sampling of millennials in Batam who considers themselves has environmentally friendly product orientation. The measurement is adopted, using 1-5 Likert scale [18]. The number of respondents is determined by a 1:5 parameter comparison (each question of the questionnaire is represented by 5 respondents) adopted from a previous study [22]. In this study, 25 questions, then the minimum number of respondents in this study is 125 respondents. The questionnaire distributed online.

Data is analyzed descriptively using SPPS, then further analysis SEM (Structural Equation Modeling) is applied. PLSSEM is considered more appropriate in this study because PLS-SEM is based on iterative that can maximize the value of the endogenous construct variance explained [22]. The CMV (Common Method Variance) test is using This Harman's technique to assess whether errors or differences in data caused by a single factor or not. The initial eigenvalue is used as the indicator of CMV that cannot be exceeded than 50\%. Outer and inner model assessment had been conducted to evaluate the vigorous of the model based on Average Variance Extracted (AVE) value > 0.5 [22]. The next inner model evaluation applied the coefficient of determination test or R Square test. It is to predict accuracy of a model. If the $\mathrm{R}$ square value indicates a value of 0.75 (strong), 0.5 (moderate) and 0.25 (weak) predictive accuracy [22].

The last step is the goodness-of-fit method, which has been developed as a whole measurement of the model on PLS-SEM, to validate the research model [23]. If the GoF value is greater than 0.1 , it can be interpreted as a small, GoF greater than 0.21 is moderate, GoF value is greater than 0.36 is Large [24].

\section{RESULTS AND DISCUSSION}

\section{A. Results}

Descriptive analysis is based on 200 sets of questionnaires successfully obtained but only 195 valid and feasible to be analyzed. The respondent is $66.7 \%$ female, the majority of 18 24 years is $90.7 \%$ with the basic income of $\$ 380 /$ month is $48.2 \%$. $46 \%$ of respondents do not aware of the practice of greenwashing or anything about greenwashing practices. It shows that Greenwashing the understanding of greenwashing practices is still limited. Based on the results of Harman's test of CMV is $49.5 \%$, it meets the standard that there are no common method biases in this study [22].

The convergent validity at the construct level which is shown by the AVE score of all variables has met the standard of minimum 0.5 . Brand credibility construct is minimum at 0.608 , Green Brand Equity construct is minimum at 0.638 , Green purchase intention construct is minimum at 0.713 and
Greenwashing construct is minimum at 0.657 . Can be seen on table 1 .

TABLE I. VALIDITY TEST RESUlTS

\begin{tabular}{|l|c|c|}
\hline \multirow{2}{*}{\multicolumn{1}{|c|}{ Constructs }} & \multicolumn{2}{c|}{ Low Involvement } \\
\cline { 2 - 3 } & $\boldsymbol{A V E}$ & Remark \\
\hline Brand Credibility & 0,608 & Accepted \\
\hline Green Brand Equity & 0,638 & Accepted \\
\hline Green Purchase Intention & 0,713 & Accepted \\
\hline Greenwashing & 0,657 & Accepted \\
\hline
\end{tabular}

The reliability test based on composite reliability shows that all variables have a CR value greater than 0.7 . Brand credibility has $\mathrm{CR}$ value is 0.915 , Green brand equity $\mathrm{CR}$ Value is 0.874 , Green purchase intention CR value is 0.908 , Greenwashing CR is 0.904. Can be seen on table 2.

TABLE II. RELIABILITY TEST RESUlts

\begin{tabular}{|l|l|l|}
\hline \multirow{2}{*}{ Constructs } & \multicolumn{2}{|c|}{ Low Involvement } \\
\cline { 2 - 3 } & $\begin{array}{c}\text { Composite } \\
\text { reliability }\end{array}$ & Remark \\
\hline Brand Credibility & 0,915 & Valid \\
\hline Green Brand Equity & 0,874 & Valid \\
\hline Green Purchase Intention & 0,908 & Valid \\
\hline Greenwashing & 0,904 & Valid \\
\hline
\end{tabular}

The Evaluation of the Outer model shows that data is clear for further analysis of inner model evaluation to see the relationship between constructs.

1) The hypothesis 1: Greenwashing has a significant negative effect on brand credibility a low involvement product is accepted. The inner test result shows that Greenwashing has a significant negative effect on brand credibility of the low involvement product of t-statistics 14.451 with a strong negative influence where the mean sample value is $-0,729$. Hypothesis 1 is accepted. It means greenwashing practices undertaken by the company will affect the brand credibility of a company negatively. This result is consistent with previous research $[14,17,9]$.

The consumer is one of the crucial stakeholders in the business chain. The Internet makes their access to information is unlimited. They can observe the DNA of the corporate culture of a firm. Since a brand is the most important intangible resource, firms are encouraged to embedded sustainability as the corporate culture than envision their long-term vision and mission. The shared vision and mission to all stakeholders will help firms gain performance in the long run.

2) The hypothesis 2: Brand credibility has a significant positive effect on green brand equity a low involvement product is accepted. Brand credibility has a significant positive effect on green brand equity in products on a low involvement product. This is evidenced by the value of the tstatistics of 6.437. It means the significance of the relationship is at the level of $5 \%$. From these results, it can be concluded that there is a significant positive effect between brand 
credibility on green brand equity so that it can prove that hypothesis 2 is accepted. The result of this study is consistent with previous studies namely $[9,15]$.

It can be explained that the role of brand credibility has influenced on brand equity in a low involvement product, in this case is bottled-mineral water. The brand credibility of consumers includes feeling good when using the product. It increases consumer confidence when using the product. Since Brand equity is a complex subset of consumer perception, when consumers feel these feelings, then indirectly the brand equity of the product appears in the minds of consumers. The main pillar of equity is credibility. This phenomenon explains that the essence of brand credibility is a firm's ability to keep the trustworthiness of customers.

3) The hypothesis 3: Green brand equity has a significant positive effect on green purchase intention a low involvement product is accepted. In this study, there is a significant positive effect between green brand equity on green purchase intention, the t-statistics value of 3.605. Its value exceeding 1.96 which means it has a significant value at the 5\% level. Hypothesis 3 is accepted. These test results are consistent with the results of previous studies namely $[9,15]$.

These results explain that consumer purchase interest is influenced by the brand equity of a firm or product. If a firm can create brand equity that can inspire and create a feeling, perception, and attention of the public, then, in the end, it can influence the buying desires of consumers.

4) The hypothesis 4: Greenwashing has a significant negative effect on green purchase intention of a low involvement product is accepted. The test results show that the value of t-statistics is 5.465 . The mean sample results from the direct effect test also show a negative effect $-0,471$. Hypothesis 4 is accepted and consistent with previous research $[9,14,15]$. The results of this study explain that greenwashing practices such as manipulation of claims and making it up by companies will affect the purchase interest of consumers of a product. When a firm does not meet the claims that have been made, it will reduce the consumer's interest in buying products because they are considered to have done public manipulation.

The DNA model can explain this clearly that the dynamic capability of a firm is the action to make the brand of firms is distinctive from others.
TABLE III. EVALUATION OF INNER MODEL

\begin{tabular}{|c|c|c|c|}
\hline Path Analysis & \multicolumn{2}{|c|}{ Low Involvement } & \multirow{2}{*}{ Remark } \\
\hline$X \rightarrow Y /$ Direct & T-Statistics & Sample Mean & \\
\hline $\begin{array}{l}\text { Greenwashing } \rightarrow \\
\text { Brand Credibility }\end{array}$ & 14,451 & $-0,729$ & $\begin{array}{l}\text { H1: Negative } \\
\text { Significant }\end{array}$ \\
\hline $\begin{array}{l}\text { Brand Credibility } \rightarrow \\
\text { Green Brand Equity }\end{array}$ & 6,437 & 0,434 & $\begin{array}{l}\mathrm{H} 2 \text { : Positive } \\
\text { Significant }\end{array}$ \\
\hline $\begin{array}{ll}\text { Green Brand Equity } \rightarrow \\
\text { Green } & \text { Purchase } \\
\text { Intention } & \\
\end{array}$ & 3,605 & 0,318 & $\begin{array}{l}\text { H3: Positive } \\
\text { Significant }\end{array}$ \\
\hline $\begin{array}{l}\text { Greenwashing } \rightarrow \\
\text { Green Purchase } \\
\text { Intention }\end{array}$ & 5,465 & $-0,471$ & $\begin{array}{l}\text { H4: Negative } \\
\text { Significant }\end{array}$ \\
\hline
\end{tabular}

\section{B. Coefficient Determination Measurement Results}

$\mathrm{R}$ square test is carried out to find out the model compatibility. In table 4 , the $\mathrm{R}$ Square value of the brand credibility, Green Brand Equity and Green Purchase Intention averagely is $57.4 \%$.

TABLE IV. COEFFICIENT DETERMINATION MEASUREMENT

\begin{tabular}{|l|l|c|}
\hline \multirow{2}{*}{ Constructs } & \multicolumn{2}{c|}{ Low Involvement } \\
\cline { 2 - 3 } & \multicolumn{1}{|c|}{ S Square } & $\%$ \\
\hline Brand Credibility & 0,535 & $53,5 \%$ \\
\hline Green Brand Equity & 0,616 & $61,6 \%$ \\
\hline Green Purchase Intention & 0,546 & $54,6 \%$ \\
\hline \multicolumn{2}{|c|}{ Source: Authors (2019) }
\end{tabular}

\section{CONCLUSION}

This study analyzes the effect of greenwashing on brand credibility, brand equity, and green purchase intention. Greenwashing has been long issue in Western and developed countries. Unfortunately, this issue is yet discussed widely in developing and emerging market academicians. This research finds that even though consumers in Batam, Indonesia is considered less educated about greenwashing practices, but greenwashing practices give a negative impact to brand credibility, brand equity, and purchase intentions even for a low involvement product.

Brand credibility is about consumers' trust and reliability of a brand. If the brand credibility is questionable from the frame of customers, it will directly affect brand equity and purchase intention. A millennial is a group of people that keen to update information about the product from social media. If they feel negative about a brand and they post it online, it will spread out faster. This condition will lead to difficulties for a firm to hide activities and pretend to be environmentally friendly. Once the customers find that the product does not meet the claim, the reputation as "a brown company" will build skepticism and negative feedback.

The object of the study is limited to bottled drinking water which is considered as a low involvement product. The behavior of millennials to high involvement products can be conducted with a broader data sample. This study does not look 
up the effect of formal education that may give respondents a better understanding of greenwashing practices. Firms need to develop a marketing strategy that accommodates the need of stakeholders as described by the DNA Model. Concerning and prioritizing the stakeholder needs is a form of a marketoriented firm. The need of stakeholders to have a long-term welfare force firm to put Sustainability as the DNA and make it as characteristics that reflected into action. It is an urgent call that firms should stop any greenwashing practices.

\section{REFERENCES}

[1] E. Loredo, N. Lopez-Mielgo, G. Pineiro-Villaverde, and M. T. GarcíaÁlvarez, "Utilities: Innovation and sustainability," Sustainability, vol. 11 , no. 4 , p. $1085,2019$.

[2] J. R. Jambeck et al., "Plastic waste inputs from land into the ocean," Science (80-. )., vol. 347, no. 6223, pp. 768-771, 2015.

[3] E. Atkin, "The Global Crisis of Plastic Pollution." The New Republic.[Online] Available at: https://newrepublic. com/article ..., 2018.

[4] M. Jefferson, "Whither plastics?-Petrochemicals, plastics and sustainability in a garbage-riddled world," Energy Res. Soc. Sci., vol. 56, p. 101229, 2019.

[5] P. Berrone, A. Fosfuri, and L. Gelabert, "Does greenwashing pay off? Understanding the relationship between environmental actions and environmental legitimacy," J. Bus. Ethics, vol. 144, no. 2, pp. 363-379, 2017.

[6] P. Aggarwal and A. Kadyan, "Greenwashing: The darker side of CSR," Indian J. Appl. Res., vol. 4, no. 3, pp. 61-66, 2014.

[7] C. N. Leonidou and D. Skarmeas, "Gray shades of green: Causes and consequences of green skepticism,” J. Bus. Ethics, vol. 144, no. 2, pp. 401-415, 2017.

[8] A. Fitrianingrum, S. Celsya, S. Mayangsari, and C. A. Ak, "ICMAE 2020."

[9] U. Akturan, "How does greenwashing affect green branding equity and purchase intention? An empirical research,” Mark. Intell. Plan., 2018.

[10] P. Bansal and K. Roth, "Why companies go green: A model of ecological responsiveness,” Acad. Manag. J., vol. 43, no. 4, pp. 717 $736,2000$.
[11] V. L. Crittenden, W. F. Crittenden, L. K. Ferrell, O. C. Ferrell, and C. C. Pinney, "Market-oriented sustainability: a conceptual framework and propositions," J. Acad. Mark. Sci., vol. 39, no. 1, pp. 71-85, 2011.

[12] M. A. Delmas and V. C. Burbano, "The drivers of greenwashing," Calif. Manage. Rev., vol. 54, no. 1, pp. 64-87, 2011

[13] R. Dahl, "Green washing: do you know what you're buying?" National Institute of Environmental Health Sciences, 2010.

[14] C.-H. Chang and Y.-S. Chen, "Managing green brand equity: The perspective of perceived risk theory," Qual. Quant., vol. 48, no. 3, pp. 1753-1768, 2014.

[15] J. Suki and J. Sasmita, "Young consumers' insights on brand equity: Effects of brand association, brand loyalty, brand awareness, and brand image,” Int. J. Retail Distrib. Manag., vol. 43, no. 3, pp. 276-292, 2015.

[16] P. F. Ng, M. M. Butt, K. W. Khong, and F. S. Ong, "Antecedents of green brand equity: an integrated approach,” J. Bus. Ethics, vol. 121, no. 2, pp. 203-215, 2014.

[17] Y.-S. Chen, A.-F. Huang, T.-Y. Wang, and Y.-R. Chen, "Greenwash and green purchase behaviour: the mediation of green brand image and green brand loyalty," Total Qual. Manag. Bus. Excell., vol. 31, no. 1-2, pp. 194-209, 2020.

[18] U. Khandelwal, K. Kulshreshtha, and V. Tripathi, "Importance of Consumer-based Green Brand Equity: Empirical Evidence," Paradigm, vol. 23, no. 1, pp. 83-97, 2019.

[19] Y.-S. Chen, "The drivers of green brand equity: Green brand image, green satisfaction, and green trust," J. Bus. ethics, vol. 93, no. 2, pp. 307-319, 2010.

[20] S. M. R. K. Panda, "Environmental consciousness and brand equity: An impact assessment using analytical hierarchy process (AHP)," Mark. Intell. Plan., vol. 35, no. 1, pp. 40-61, 2017.

[21] V. Q. I. Phau, "Marketing Intelligence \& Planning Article information," Mark. Intell. Plan., vol. 32, pp. 89-106, 2014.

[22] J. F. Hair Jr, M. Sarstedt, L. Hopkins, and V. G. Kuppelwieser, "Partial least squares structural equation modeling (PLS-SEM)," Eur. Bus. Rev., 2014.

[23] J. Henseler, C. M. Ringle, and M. Sarstedt, "Using partial least squares path modeling in advertising research: basic concepts and recent issues," in Handbook of research on international advertising, Edward Elgar Publishing, 2012.

[24] J. F. Hair, J. J. Risher, M. Sarstedt, and C. M. Ringle, "When to use and how to report the results of PLS-SEM,” Eur. Bus. Rev., 2019. 